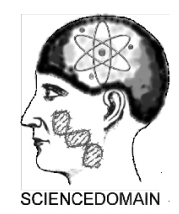

\title{
The Link between Remittances and Economic Growth in Pakistan: A Boon to Economic Stability
}

\author{
Khalid Al Khathlan ${ }^{1^{*}}$ \\ ${ }^{1}$ Economics Department, King Saud University, Riyadh, P.O .Box 2459, 11451, \\ Kingdom of Saudi Arabia.
}

Research Article

Received 31 ${ }^{\text {st }}$ March 2012

Accepted 17 $7^{\text {th }}$ June 2012

Published 6 ${ }^{\text {th }}$ August 2012

\section{ABSTRACT}

This paper adopted the autoregressive distributed lag (ARDL) test and the error correction model (ECM) techniques to establish the long-run and short -run relationship between worker remittances and economic growth in Pakistan during the period 1976-2010. The results demonstrate the existence of a positive and significant relationship between worker remittances and economic growth in the long-run and short-run in that country. Worker remittances act as an important source of foreign capital, while a significant component of BOP serves as a boon to the economy. The gross fixed capital formation has a positive and significant impact on economic growth in the short run. The negative role in the long run in the presence of such financial flows shows the inappropriateness of policy measures aimed at boosting real sectors of the economy. FDI has a positive and significant impact on economic growth in the short run and long run.

Keywords: Worker remittances; GDP; FDI; export; inflation; ARDL; ECM; IRF.

\section{INTRODUCTION}

Worker remittances have attracted considerable debate among academics, policy makers and researchers regarding their possible impact on the growth and development of developing countries. Many studies have examined various sources of growth, including the use of surplus labor in development, the adoption of new technologies, foreign aid, foreign direct investment (FDI) and returns on investment (Lewis, 1954; Solow, 1956; Denison, 
1967; Romer, 1986; Barro, 1991). Worker remittances have been recognized as an important and stable source of foreign income in developing countries. Specifically, developing countries use remittances to their advantage by bridging the balance of payments (BOP) gap and thus addressing inflation issues that arise on account of economic development programs. This is also beneficial to a labor-surplus country on account of its structural adjustment programs with respect to the outflow of capital for interest payments and the growing demand for imports. It also allows workers to support their families and relatives during financial crises and natural calamities (Orozco, 2003; Ratha, 2007). As such, the inflow of remittances generally tends to lead to the reduction of poverty level, the acquisition of skills and techniques, improvements in health conditions and educational access and other benefits.

Pakistan is primarily an agricultural-based economy with a real per-capita GDP of US $\$ 669$ along with a rising unemployment rate, which reached 5.6 percent in $2010^{1}$. The country has faced a rising emigration rate since the late 1970s, which provided the country with a significant amount of remittances- and, moreover, it's largest - source of foreign capital. With a dwindling share of agriculture and the unavailability of appropriate means to earn a livelihood, Pakistani workers have often migrated to obtain better employment opportunities, higher wages and better working environments ${ }^{2}$ (Ahmed et al., 2011). A migrant's remittance serves as a means to boost the economy as an important source of foreign exchange and a significant component of BOP accounts. Iqbal and Sattar (2005) observed that remittances affect economic growth by reducing a country's current account deficit, improving its BOP position and also by reducing its dependency on external borrowings. Remittances also affect the economic growth by increasing domestic demand, raising savings and investments, improving labor skills and reducing external debt. Shahbaz et al. (2008) observed that worker remittances made it possible to receive a large chunk of financial flows in the economy. The flows of worker remittances have a multiplier effect on income, economic output and employment ${ }^{3}$. Remittances are spent on improving living conditions, creating real estate and leading to the acquisition of new technology. Nishat and Bilgrami (1991) observed a multiplier intensity of 2.4 in an empirical study using a simple Keynesian model. They conclude that worker remittances have a positive impact on consumption, investments and imports in Pakistan. Anwar (2004) observed that worker remittances had a positive social and economic effect on households during 1980s. He also observed that an increase in remittances have led to a decrease in the poverty level.

1. Agriculture is the main source of livelihood, providing more than $45 \%$ employment; in rural areas, this figure is 63.4\% (WDI, 2011; State Bank of Pakistan, 2011).

2. Burney $(1987 ; 1988)$ studied the impact of remittances on Pakistan and found that migrants tend to earn five to eight times more and remitted 77 percent of their earnings. This has become an important component of BOP, accounting for 10.1 percent of the GDP and financing 84.8 percent of the current account deficit and 96.6 percent of the trade deficit in the fiscal year of 1982.

3. For more on the effectiveness of migrant remittance, see also Stahl and Arnold (1986), Adams (1998), Adams and Page (2003), Guilano and Arranz (2005) and Kalim et al. (2008). 
There appears to be a significant relationship between worker remittances and economic growth in Pakistan due to its impact on domestic capital formation, financial development, human development, trade and commerce development and so on. Hence, there is a pressing need to evaluate the relationship between migrant remittances and growth in Pakistan.

This paper is an attempt to empirically examine the relationship between worker remittances and economic growth in Pakistan by using the Bounds testing approach. The remainder of the study is organized as follows. Second section presents the literature review, including recent developments on the subject. Third section outlines the model specification, data and methodology. Fourth section presents the Bounds testing technique and the empirical results. Last section concludes the paper with important findings and suggestions for future work.

\section{RECENT TRENDS IN REMITTANCES AND ECONOMIC GROWTH}

Worker remittances have increased rapidly, growing to more than three times the value of Official Development Assistance (ODA), being second only to FDI flows in developing countries. Worker remittances in developing countries reached US $\$ 280.8$ billion in 2009; they accounted for 42.1 percent of all external sources of financial flows, including official and FDI flows to developing countries (UNCTAD, 2011). In 2010, remittances received by developing countries reached US\$325 billion, and they are expected to grow to US\$346 billion by 2011 and US $\$ 374$ billion by 2012 (World Bank, 2011).

Fig. 1 provides the top 15 remittance recipient countries in 2010. Among these countries, Pakistan is 11th, with remittances of US $\$ 9.7$ billion; this accounts for 3.2 percent of remittances to developing economies and 2.1 percent of remittances globally. During the 1970s, Pakistan's BOP worsened on account of its high import bill due to the impact of oil shocks to the economy. By this time, the Gulf Cooperation Council (GCC) region began widely hiring Pakistanis workers. This hiring trend resulted in an increase in worker remittances to Pakistan in the late 1970s, which continued through the 1980 s.

Table 1 shows that worker remittances increased from 6.0 percent of the GDP during 197679 to 8.6 percent during the 1980 s. Worker remittances became the largest source of external finance, outpacing ODA (US\$1.0 billion) and FDI (US\$ 0.1 billion) during the 1980s. In the decade of 1980 s, worker remittances accounted for an annual average of 65.3 percent of the trade deficit, more than double the country's current account deficit and more than four times the interest payment of the BOP account; thus, remittances emerged as a boon to the economy. The GDP growth rate increased from an average annual growth of 5.2 percent during 1976-79 to 6.9 percent during the 1980 s. The rise in worker remittances to Pakistan during the 1980s is due to the migration of Pakistani workers to Middle Eastern countries from 79,000 during the 1970 s to 107,000 during the 1980 s (Shahbaz et al., 2008). This was followed by a decline in the current account deficit from 5.0 percent of the GDP during 197679 to 2.7 percent during the 1980 s.

The trade deficit declined from 18.4 percent of the GDP during 1976-79 to 10.6 percent during the 1980s. The economy recorded an improvement in FDI inflows during 1980s. Kalim et al. (2008) observed that worker remittances had positive economic and social effects on households in Pakistan during the 1980s. They observed that migrants from the Middle East remitted around 75 percent of their earnings during the decade. Recipient 
households spent 42 percent of remitted income on basic family requirements, 29 percent on other consumer items and 13 percent on investments.

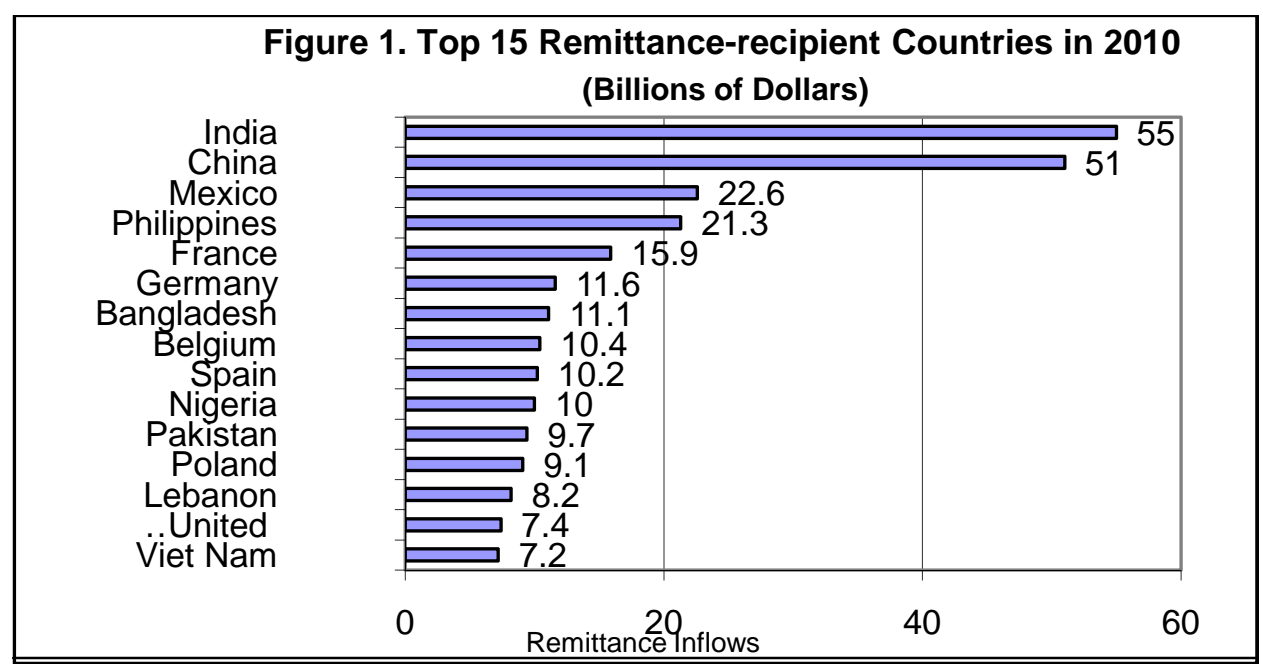

Fig. 1. Top 15 remittance-recipient countries in 2010

Sources: World Development Indicators (WDI), Online Statistics, World Bank, 2011.

During the 1990s, worker remittances declined by 35 percent and became 3.6 percent of the GDP compared to 8.6 percent during the 1980s. This could be due to the eruption of the Gulf War in the beginning of the 1990s. Worker remittances remained the largest source of foreign finance, but they declined to 34.6 percent of Pakistan's trade deficit.

The GDP growth rate declined from 7.3 percent during the 1980 s to 4.6 percent during the 1990s. This decline is partly due to the eruption of the Gulf crisis in early 1990s, the imposition of sanctions and the seizure of Pakistani foreign accounts due to the 1998 nuclear explosion (Asghar and Ashfaq, 2004). The decline in worker remittances have resulted in an increased general price level in the economy and an increase in the current account deficit to 4.0 percent of the GDP during the 1990s, up from 2.7 percent during the 1980s. The trade deficit also declined from 10.6 percent of the GDP during the 1980s to 3.1 percent during 1990s. This may be due to additional FDI and ODA as well as macroeconomic adjustments during the 1980s.

Table 1 shows continuously rising trend of remittances during 2000 to 2010 particularly compared to previous decades. The GDP growth rate also increased from an average annual growth rate of 4.6 percent during the 1990 s to 4.7 percent during the 2000 s. This led to an improvement in general investment and a decline in the price level in the economy. On the external front, Pakistan has been able to bring down the current account deficit from 4.0 percent of the GDP during the 1990s to 1.5 percent during the 2000 s, while the trade deficit of 3.1 percent of the GDP has become a trade surplus of 0.8 percent during the same period. Similarly, Pakistan's access to FDI increased from 0.7 percent of the GDP during the 1990 s to 1.8 percent during the 2000s. 
Table 1. Growth Performance of the Real GDP and Worker Remittances along With GFCF, FDI and Inflation in Pakistan during 1976-2010

\begin{tabular}{|c|c|c|c|c|c|c|c|c|c|c|c|}
\hline & \multicolumn{11}{|c|}{ US\$ Billion } \\
\hline & 1976-79 & 1980s & 1990s & 2000s & 2000-04 & 2005 & 2006 & 2007 & 2008 & 2009 & 2010 \\
\hline $\begin{array}{l}\text { Real GDP }(\% \\
\text { average annual) } \\
\text { Worker } \\
\text { Remittances } \\
\text { (\% of GDP) }\end{array}$ & $23.0(5.2)^{*}$ & $37.1(7.3)$ & $161.3(4.6)$ & $91.7(4.7)$ & $79.3(4.3)$ & $94.4(7.7)$ & $101.0(6.2)$ & $105.9(5.7)$ & $107.6(1.6)$ & $111.4(3.6)$ & $116.1(4.4)$ \\
\hline $\begin{array}{l}\text { GFCF (\% of GDP) } \\
\text { FDI Inflows } \\
\text { (\% of GDP) } \\
\text { Current Account }\end{array}$ & $\begin{array}{l}5.0(17.5) \\
0.03(0.1) \\
-08(-50)\end{array}$ & $\begin{array}{l}7.6(17) \\
0.1(0.2)\end{array}$ & $\begin{array}{c}11.4(18.1) \\
0.5(0.7)\end{array}$ & $\begin{array}{c}14.5(17.4) \\
2.3(1.8)\end{array}$ & $\begin{array}{c}12.2(15.4) \\
0.6(0.8)\end{array}$ & $\begin{array}{c}13.6(17.5) \\
2.2(2.0) \\
-36(-3.3)\end{array}$ & $\begin{array}{c}16.3(20.5) \\
4.2(3.4) \\
-6.8(-5.3)\end{array}$ & $\begin{array}{c}18.5(20.9) \\
5.5(3.1)\end{array}$ & $\begin{array}{l}19.2(20.5) \\
5.4(3.7) \\
-56(-96)\end{array}$ & $\begin{array}{c}16.9(17.4) \\
2.3(1.5)\end{array}$ & $\begin{array}{l}15.9(15) \\
1.9(1.1)\end{array}$ \\
\hline Trade Deficit & $\begin{array}{l}-0.8(-5.0) \\
-0.1(-18.4)\end{array}$ & $\begin{array}{l}-0.9(-2.7) \\
-3.7(-10.6)\end{array}$ & $\begin{array}{l}-2.2(-4.0) \\
-2.0(-3.1)\end{array}$ & $\begin{array}{c}-3.0(-1.5) \\
6.9(0.8)\end{array}$ & $\begin{array}{c}-1.7(-2.3) \\
1.4(1.6)\end{array}$ & $\begin{array}{c}-3.6(-3.3) \\
0.7(0.7)\end{array}$ & $\begin{array}{l}-6.8(-5.3) \\
-7.2(-0.7)\end{array}$ & $\begin{array}{c}-8.3(-5.8) \\
0.4(0.4)\end{array}$ & $\begin{array}{l}-5.6(-9.6) \\
-1.3(-1.2)\end{array}$ & $\begin{array}{l}-4.0(-2.5) \\
0.05(0.9)\end{array}$ & $\begin{array}{c}-1.5(-0.8) \\
3.1(2.7)\end{array}$ \\
\hline $\begin{array}{l}\text { Net ODA } \\
\text { Interest payments } \\
\text { on External Debt } \\
\text { Inflation (\% annual } \\
\text { average) }\end{array}$ & $\begin{array}{l}0.7 \\
0.2 \\
7.9\end{array}$ & $\begin{array}{l}1.0 \\
0.0 \\
8.4\end{array}$ & $\begin{array}{l}11.0 \\
1.0 \\
10.6\end{array}$ & $\begin{array}{l}11.8 \\
0.9 \\
8.0\end{array}$ & $\begin{array}{l}11.5 \\
0.9 \\
2.0\end{array}$ & $\begin{array}{l}11.6 \\
0.7 \\
9.1\end{array}$ & $\begin{array}{l}22.1 \\
0.9 \\
7.9\end{array}$ & $\begin{array}{l}1.1 \\
7.6\end{array}$ & $\begin{array}{l}11.5 \\
1.1 \\
20.3\end{array}$ & $\begin{array}{l}2.8 \\
1.0 \\
20.3\end{array}$ & $\begin{array}{l}1.1 \\
13\end{array}$ \\
\hline
\end{tabular}

Sources: World Development Indicators (WDI), 2011. Online Statistics, World Bank, 2011.

${ }^{*}$ Numbers in Parenthesis are in percentages. 
After the mid-2000s, the economy started showing negative trends, with its GDP growth rate declining to its lowest level of 1.6 percent in 2008 together with rising price levels and a double-digit inflation rate of 20.3 percent. However, the economy recorded an improvement in worker remittances and FDI, despite mixed results with respect to BOP. These improvements are likely to affect the pace of economic activities and reduce supply bottlenecks in the economy. To boost the inflow of worker remittances, the government has implemented the new Pakistan Remittance Initiative ${ }^{4}$ (PRI) to facilitate the smooth flow of remittances into the country.

Fig. 2 depicts the trends in worker remittances and the GDP growth rate in Pakistan from 1976 to 2010 . Worker remittances increased from 6.0 percent of the GDP during 1976-79 to 7.5 percent during $1980 \mathrm{~s}$. The average annual GDP growth rate increased from 5.2 percent during $1976-79$ to 7.3 percent during the 1980 s.

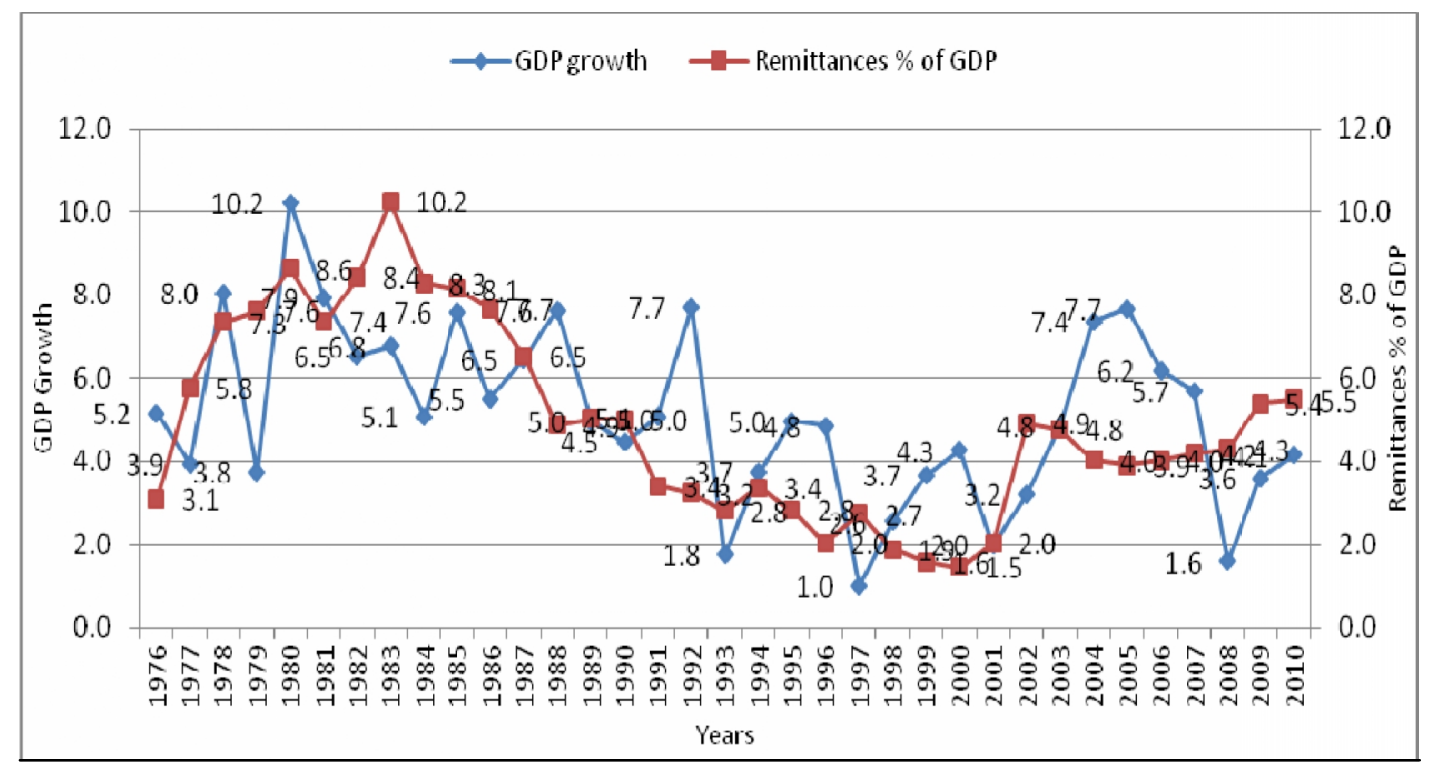

Fig. 2. GDP growth and remittances as a \% of GDP (1976-2010)

Sources: World Development Indicators (WDI), Online Statistics, World Bank, 2011.

The figure shows a positive link between the inflow of worker remittances and the GDP growth rate. Worker remittances recorded a decline from 8.6 percent during the 1980 s to 3.9 percent during the 1990s. The GDP growth rate also recorded a decline from 7.3 percent during the 1980 s to 4.6 percent during the 1990s. The trends in worker remittances and the GDP growth rate show a decline during the decade of the 1990s. The first half of the 2000s shows a positive trend in the worker remittances and growth rate of the GDP. Worker remittances increased from 4.3 percent in 2008 to 5.5 percent in 2010 . Similarly, the GDP growth rate also shows a positive trend from 1.6 percent in 2008 to 4.4 percent in 2010 .

4 This was a joint initiative by the State Bank of Pakistan, the Ministry of Finance and the Ministry of Overseas Pakistanis aimed at assisting the fast, financially feasible and convenient flow of remittances through normal channels. 


\section{LITERATURE REVIEW}

In recent years, worker remittances have grown rapidly to become one of the major sources of external financing in developing countries. Worker remittances are considered a stable source of foreign income and growth promotion in an economy. It is the second largest source of external finance to many developing countries. It tends to accelerate the pace of economic development with increased domestic saving and investment in the recipient countries. The opposite views is that migration as a tenet of brain drain in the sphere of globalization makes human capital more scarce where it is already scarce and make it more abundant where it is more abundant and thereby increasing inequality across the countries including among the richer ones (Docquier and Rapoport, 2006). McCormick and Wahba (2002) observed that worker remittances increase the level of domestic investment in migrant home countries. Economists such as Owens (1987) and Kaufmann and Mastruzzi (2006) have observed that the impact of worker remittances depends on institutional factors such as political freedom, political instability, political voice and accountability in terms of economic growth and development. Carlos and Huang (2006) observed that worker remittances tend to increase with better macroeconomic conditions in the host country relative to the home country. Catriescu et al. (2006) found thatthe impact of remittances on growth vary with the soundness of the institutional environment in the recipient country.

Giuliano and Ruiz-Arranz (2005) observed that worker remittances have surpassed the FDI, export revenue and foreign aid in a number of developing countries. World Bank (2006) found that worker remittance became greater than FDI or ODA due to their effectiveness in remittance recipient countries. Rajan (2006) observed that FDI, worker remittances and export revenue are relatively more stable source of capital inflow as compare to foreign aid and debt. Stark and Bloom (1985) observed that worker remittances are used by workers to increase their wealth, enhance their income and ensure against future vulnerabilities. Faini (2002) observed that the impact of financial flows on economic growth depends on growth prospects and the investment climate in migrant home countries. He argued that worker remittances serve as a means to counter financial stocks such as crops failures and adverse trading and to maintain consumption levels.

Worker remittances serve a dual role in recipient countries, both enhancing the productive capacity of the economy and generating greater demand. Adams (1998) observed that inward remittances do have a positive impact on domestic savings and economic investment. Adams and Page (2003) observed that worker remittances are expected to enhance income and to reduce poverty among recipients at the micro level. Lucas and Stark (1985) and Adams 1991) found that worker remittances have reduced the poverty rate. Giuilano and Arranz (2005) observed that worker remittances have a positive impact on economic growth because they facilitate credit access among the poor and aid in the development of the financial sector. Jongwanich (2007) found that worker remittances have a significant influence on poverty reduction and increased standard of living.

In a study of 37 African countries, Fayissa and Nsiah (2008) observed that worker remittances have a positive impact on economic growth. Habib and Nourin (2006) observed that the impact of worker remittances on economic growth is mixed in South and South East Asian economies. The study finds that there is negative relationship between migrant remittance and per-capita GDP growth in Thailand, Srilanka, India and Indonesia, whereas this relationship is positive in Bangladesh, Pakistan and Philippines. Burney (1988) studied the impact of remittances in Pakistan and found that migrants tended to earn five to eight 
times more than the home country and they remitted more than 77 percent of their earnings to Pakistan.

Although developing countries benefit from worker remittances, they also suffer the loss of skilled, educated workers, which may affect output and, therefore, reduce revenue to the government. Other studies have observed that worker remittances have a minimal impact on investment and are mainly used for consumption purposes. Reichart (1981) used the term 'migrant syndrome' to explain remittances as a compensatory transfer against the loss of human capital. This may produce the so-called 'Dutch Disease' effect by increasing demand for labor along with increases in the production of goods and services in the economy. Chami and Jahjal (2003) observed that worker remittances have a negative impact on economic growth because most of the remittance income is spent on consumption goods and to build houses, purchase land or acquire jewelry.

\section{MODEL SPECIFICATION}

The purpose of the study is to analyze the empirical relationship between economic growth and worker remittances in Pakistan during the period 1976-2010. We anticipate a positive impact of worker remittances on economic growth in Pakistan. Thus, we began our study by modeling the relationship between economic growth and worker remittances.

$Y=f(W R, G F C F, F D I, E P)$

Where $(Y)$ indicates the real GDP, (WR) indicates worker remittances, (GFCF) indicates gross fixed capital formation, (FDI) indicates foreign direct investment and (EP) indicates exports from Pakistan.

Many studies have used worker remittances, gross fixed capital formation, FDI and exports to analyze the relationship between worker remittance and economic growth (de Mello, 1997; De Gregorio, 2003; Kemal, et al., 2002; Narayan, 2005; Ahmed et al., 2011). The relationship can be expressed as

$$
Y_{t}=\partial_{t}+\alpha W R_{t}+\beta G F C F_{t}+\delta \mathrm{FDI}_{t}+\theta E P_{t}+E_{t} \ldots \ldots \ldots \text {.eq.(i) }
$$

This study uses a log-linear modeling specification to quantify the remittance-growth relationship in Pakistan for the period 1976-2010. Log-linear modeling is superior to other approaches on theoretical and empirical grounds, and it is likely to have a deterrent effect on the outcome, as suggested Layson (1983), Cameron (1994) and Kalim and Shahbaz (2009). In light of the above literature, the remittance-growth relationship equation (i) can be modified into a logarithmic $(L)$ form as follows.

$$
L Y_{t}=\partial_{t}+\alpha L W R_{t}+\beta L G F C F_{t}+\bar{o} L F D I_{t}+\theta L E P_{t}+E_{t}
$$

Moreover, in Pakistan, the economy faces double-digit inflation. It has been observed that a high inflation rate reduces economic growth, GCF and manufacturing activity and degrades the value of the currency. Therefore, inflation (INF) is included in our empirical model analysis (Gylfason, 1999; Hodge, 2006). To test the model, empirically we present the final form of the model as follows.

$$
L Y_{t}=\partial_{t}+\alpha L W R_{t}+\beta L G F C F_{t}+\bar{o} \mathrm{LFDI}_{t}+\theta L E P_{t}+\lambda L I N F_{\mathrm{t}}+E_{t}
$$


Where

LY $=$ Represents the real GDP

LWR = Remittances as a percentage of the GDP

LGFCF $=$ Gross fixed capital formation as a percentage of the GDP

LFDI $=$ FDI as a percentage of the GDP

LEP = Exports as a percentage of the GDP

LINF = Rate of inflation

\subsection{Methodology}

\subsubsection{The Bounds Testing Approach}

This section uses the Augmented Dickey Fuller (ADF) test and the Phillips-Perron test to establish the time series properties of the data. In particular, this study applied the Bounds testing technique developed by Pesaran et al. (2001) to trace the long-run and short-run relationships between LGDP, LWR, LGCF, LFDI, LEP and LINF in the case of Pakistan. The ARDL technique has unique properties; in particular, the test is applicable to data, regardless of whether the variables are integrated of order I(0) or I(1).

Vector Autoregressive (VAR) approach of order $\rho$, can be described as follows:

$$
z_{t}=\phi+\sum_{i=1}^{p-1} \delta_{i} z_{t-i}+\varepsilon_{t} \ldots \ldots \ldots . . . \quad e q .(i v)
$$

where $Z_{t}$ represents the vector of variables $\left(Y_{t}\right)$ and $\left(X_{t}\right)$ and $Y_{t}$ is a dependent variable and $X_{t}$ represent the set of explanatory variables, including, LWR, LGCF, LFDI, LEP and LINF.

The ARDL technique requires that the dependent variable (LY) be integrated of order I(1) while the explanatory variables can be a mixture of orders $I(0)$ and $I(1)$. The above equation can be further modified into a vector error correction model (VECM) as follows.

$$
\Delta z_{t}=\phi+\pi_{t}+\delta z_{t-1}+\sum_{i=1}^{P-i} \partial_{t} \Delta Y_{t-i}+\sum_{i=1}^{p-1} \partial_{t} \Delta X_{t-i}+\varepsilon_{t} \ldots \ldots \ldots \ldots \ldots . . . . . . . . .(v)
$$

Where, $\Delta$ represents the first difference. The coefficient $\delta$ represents the long-run multiplier matrix, which is expressed as follows.

$$
\delta=\left(\begin{array}{ll}
\delta_{Y Y} & \delta_{X X} \\
\delta_{X Y} & \delta_{X X}
\end{array}\right)
$$

The series can be integrated of order $\mathrm{I}(0)$ or $\mathrm{I}(1)$ due to the unrestricted diagonal elements of matrix $\delta_{Y Y}$. When $\delta_{Y Y}$ is equal to zero, the dependent variable $\left(L Y_{t}\right)$ will be integrated of $I(1)$. Meanwhile, if it is less than the dependent variable, with $\delta_{Y Y}<0$, it will be integrated of order $\mathrm{I}(0)$. One implication of the VECM model is that the test is able to determine one cointegrating vector among the set of explanatory variables $X_{t}$. This is facilitated by the use of the unrestricted error correction model (UECM) and OLS techniques. The remittancegrowth model for short-run and long-run periods can be stated as follows. 


$$
\begin{aligned}
& \Delta L Y_{t}=\alpha_{0}+\sum_{i=1}^{n-1} \alpha_{1 i} \Delta L Y_{t-i}+\sum_{i=0}^{n-1} \alpha_{2 i} \Delta L W R_{t-i}+\sum_{i=0}^{n-1} \alpha_{3 i} \Delta L G F C F_{-i}+\sum_{i=0}^{n-1} \alpha_{4 i} \Delta F D I_{t-i}+\sum_{i=0}^{n-1} \alpha_{5 i} \Delta L E P+\sum_{i=o}^{n-1} \alpha_{6 i} \Delta L I N F \\
& \quad+\beta_{1} L Y_{t-1}+\beta_{2} L W R_{t-1}+\beta_{3} L G F C F_{t-1}+\beta_{4} L F D I_{t-1}+\beta_{5} L E P_{t-1}+\beta_{6} L I N F_{t-1}+\varepsilon_{t} \ldots . . \text { eq.(vi) }
\end{aligned}
$$

Where $\Delta$ represents the first difference and $\varepsilon_{t}$ is a disturbance term in the model. Equation (vi) shows that in the short run and long run, economic growth is being influenced by its past values. The appropriate lag length in the model is based on the Schwarz Bayesian Criteria (SBC) criteria. The Bounds test is conducted by imposing restrictions on the coefficients of the long-run relationship, namely, that are LY, LWR, LGFCF, LFDI, LEP and LINF in the Pakistan economy.

The null hypothesis that there is a no cointegrating vector among the variables such that $\mathrm{H}_{0}: \beta_{1}=\beta_{2}=\beta_{3}=\beta_{4}=\beta_{5}=\beta_{6}=0$, whereas the alternative hypothesis is that there exists a long-run relationship such that $H_{1}: \beta_{1} \neq \beta_{2} \neq \beta_{3} \neq \beta_{4} \neq \beta_{5} \neq \beta_{6} \neq 0$.

The outcomes of the Bounds test, that is, the F-test statistics, indicate whether the null hypothesis should be accepted or rejected. If the value of the F-test statistic is greater than the upper limit of the critical values (Pesaran et al., 2001), then we reject the null hypothesis of no cointegration among the variables. However, if the value of the Bounds test statistic is less than the lower limit of the bounds value, then we accept the null hypothesis of no cointegration among the variables in the model. If the value of the F-test statistic falls between these two bounds, then the results are inconclusive.

When the Bounds test demonstrates the existence of cointegration, the long-run model for the dependent variable $\left(L Y_{t}\right)$ can be estimated after taking into account to the appropriate lag length based on the SBC.

$$
\begin{aligned}
& L Y_{t}=\beta_{0}+\sum_{i=1}^{n} \beta_{1 i} L Y_{t-i}+\sum_{i=0}^{n} \beta_{2 i} L W R_{t-i}+\sum_{i=0}^{n} \beta_{3 i} L G F C F_{t-i}+\sum_{i=0}^{n} \beta_{4 i} L F D I_{t-i}+\sum_{i=0}^{n} \beta_{5 i} L E P_{t-i} \\
& +\sum_{i=0}^{n} \beta_{6 i} L I N F_{t-i}+\varepsilon
\end{aligned}
$$

The short-run model for the dependent variable (LY) can be estimated by applying the error correction model (ECM) techniques as follows.

$$
\left.\Delta Y_{t}=\partial_{0}+\alpha_{1 i} \sum_{i=1}^{n-1} \Delta Y_{t-i}+\beta_{1 i} \sum_{i=0}^{n-1} \Delta W R_{t-i}+\phi_{1 i} \sum_{i=0}^{n-1} \Delta G F C F_{t i}+\delta_{1 i} \sum_{i=0}^{n-1} \Delta F D I_{t-i}+\theta_{1 i} \sum_{i=0}^{n-1} \Delta E P_{t-i}+\beta_{1 i} \sum_{i=0}^{n-1} \Delta I N F+\omega E C M-1\right)+\mu_{t}
$$

Where $\mathrm{ECM}_{-1}$ is the error correction term, define as

$$
\begin{aligned}
& E C M=L Y_{t}-\beta_{0}-\sum_{i=1}^{n} \beta_{1 i} L Y_{t-1}-\sum_{i=1}^{n} \beta_{2 i} L W R_{t-1}-\sum_{i=0}^{n} \beta_{3 i} L G F C F_{t-1}-\sum_{i=0}^{n} \beta_{4 i} L F D I_{t-1}-\sum_{i=0}^{n} \beta_{5 i} L E P_{t-1} \\
& -\sum_{i=0}^{n} \beta_{6 i} L I N F_{t-1}+\varepsilon
\end{aligned}
$$

Where, the coefficients in this model are short-run dynamic coefficients that adjust in the long-run equilibrium. Note that $\omega$ coefficient is expected to have a negative sign and reflect the speed of adjustment in the model. The impact of worker remittances on economic growth 
cannot be ignored due to its possible multiplier effect (Stahl and Arnold, 1986). A number of studies have shown that worker remittances play a positive role; thus, the coefficient for remittances is expected to have a positive sign. FDI plays an important, positive role in the economic growth and development of developing countries (De Mello, 1997; Borensztein, et al., 1998; De Gregorio, 2003). Empirical studies reveal that exports have a positive impact on economic growth. Specifically, Kemal et al. (2002); Krueger (1978); Tyler (1981); Balassa (1985); Salvatore and Hatcher (1991); Khan and Saqib (1993); Vohra (2001) have observed that exports induce economic growth and this is expected to affect economic growth positively. Gylfason (1999); Hodge (2006) observed that inflation reduces economic growth due to its long-term implications for the stability of growth-inductive factors in the economy.

\subsubsection{Empirical results}

This study applied the ADF test; the results are presented in Table 2, which shows that variables are non-stationary with respect to level and stationary with respect to first difference. The study also applied the Phillips-Perron unit root test to confirm the outcome of the ADF test.

Table 2. Unit root

\begin{tabular}{lllll}
\hline Variables & ADF & & \multicolumn{2}{l}{ Phillips-Perron } \\
\cline { 2 - 5 } & Level & First difference & Level & First difference \\
\hline LY & -2.567 & $-4.108^{*}$ & 2.546 & $-4.153^{*}$ \\
LWR & -1.548 & $-4.818^{*}$ & 1.823 & $-4.820^{*}$ \\
LGFCF & -3.558 & $-3.826^{*}$ & 2.479 & $-3.681^{*}$ \\
LFDI & -2.001 & $-5.132^{*}$ & 2.001 & $-5.102^{*}$ \\
LEP & -1.736 & $-5.806^{*}$ & 1.654 & $-5.808^{*}$ \\
LINF & -4.120 & $-6.383^{*}$ & 2.334 & $-6.379^{*}$ \\
\hline \multicolumn{4}{r}{ Notes: Unit root test is conducted using the ADF test (Mckinnon, 1996) and Phillips } \\
\multicolumn{2}{r}{ and Perron. Test. The asterisk * indicates significance at the 5\% and 1\% levels. }
\end{tabular}

Following the UECM version of the ARDL techniques developed by Pesaran et al. (2001), the appropriate lag length selected by the SBC is used in the model. Table 3 presents the results of the Bounds testing technique, which was used to examine the long-run relationship between economic growth, worker remittances, gross investment, FDI, exports and inflation.

Table 3. Bounds test results for cointegration

\begin{tabular}{lllllll}
\hline F-test Statistic = 8.635 & \multicolumn{10}{l}{ Upper } & Bounds Values \\
\hline Pesaran et al. (2001) & \multicolumn{1}{l}{ Lower } & Bounds values & \multicolumn{4}{l}{} \\
\cline { 2 - 7 } & $10 \%$ & $5 \%$ & $1 \%$ & $10 \%$ & $5 \%$ & $1 \%$ \\
& 3.15 & 2.45 & 2.12 & 4.43 & 3.61 & 3.23 \\
\hline
\end{tabular}

Notes: The Bounds test values are based on Pesaran et al. (2001). Table Cl (iii) Case III: Unrestricted intercept \& No trend. Denotes significance at 10\%, 5\% \& $1 \%$.

The computed F- test statistic is based on the Wald test, and it is greater than the upper bounds critical values presented by Pesaran et al. (2001). This establishes a long-run relationship between the variables under study. 
Table 4 presents the estimates of the long-run relationship between LY, LWR, LGFCF, LFDI, LEP and LINF as specified in equation (vii). The results demonstrate that the long-run relationship between economic growth and worker remittances is positive and significant. Similarly, there is a positive relationship between FDI, exports and economic growth. However, as expected, the results show a negative relationship between inflation and economic growth. This could be due to the high cost of manufacturing activities, which leads to a general rise in the price level in the economy. The high rate of inflation discourages high- cost investment and lowers the export competitiveness of the country.

Table 4. Estimated Long-run Coefficients for the ARDL Model Dependent variable: Real GDP (LY)

\begin{tabular}{lllll}
\hline Variables & Coefficients & Std. Error & t-statistics & p-value \\
\hline C & 8.494 & 0.264 & 3.491 & 0.003 \\
LWR & 0.421 & 0.009 & 5.192 & 0.000 \\
LGFCF & -0.023 & 0.050 & -0.050 & 0.961 \\
LFDI & 0.221 & 0.011 & 2.195 & 0.043 \\
LEP & 0.200 & 0.029 & 0.753 & 0.462 \\
LINF & -0.101 & 0.009 & -1.248 & 0.230 \\
\hline
\end{tabular}

Diagnostic Tests: $R$-square $=0.844 ;$ Adjusted $R$ Square $=0.697$; Jarque-Bera Normality test 6.601(0.040); Breusch-Godfrey Serial Correlation test = 3.951(0.139); $A R C H$ Heteroscedasticity test = 0.496(0.739); andRamsay Reset Regression specification Error test $=1.366(0.287)$. The values in the parenthesis show $p$-values.

In the long-run, $\log (\mathrm{GDP})=0.3^{*} \log$ (remittances). $\mathrm{LWR}$ represents a ratio to GDP, so it can be written as $\log ($ GDP $)=0.42^{*}(\log ($ remittances $)-\log (G D P))$ and $0.3=0.42 / 1.42$. It implies that $1 \%$ increase in remittances induce $0.3 \%$ increase in GDP.

The diagnostic tests presented at the bottom of table 4 confirm that the estimated equation (vii) possesses the desired statistical properties. Diagnostic tests such as the Godfrey Serial correlation LM test, Jarque-Bera test for normality, ARCH test for Heteroskedasticity and Ramsey RESET test for model specification confirm the validity of the estimated equation. Moreover, the CUSUM and CUSUM Square test signifies that residual values are stable and within the critical 5 percent critical boundaries (Appendix. 1).

Table 5 presents the short-run dynamic coefficients for the long-run relationship elaborated in the ECM equation (viii). The results show that the ECM coefficient is negative and significant. Specifically, estimated coefficient of the ECM is 11 percent, showing a slow speed of adjustment from the previous year to the long-run equilibrium. The results show that the effects of LWR, LGFCF and LFDI are positive and significant, contributing 2 percent, 21 percent and 2 percent to economic growth, respectively. The small size of remittances in the short-run may be due to the role of remittances in meeting domestic requirements and their use as an instrument against short-run cyclical fluctuations.

The estimated outcomes of the long-run and short-run coefficients reveal the positive role of worker remittances on economic growth in Pakistan. FDI effects economic growth positively, but the low and insignificant effect of investments suggests the inappropriateness of investment policies aimed at enhancing the economy. This tendency is likely to reduce the intensity of exports and create supply bottlenecks in the economy, discouraging investment, increasing demand and, therefore, raising the price level in the economy. 
Table 6 presents the results of the VEC Granger Causality tests based on the Wald test statistics; these results show the direction of causality between the variables LY, LWR, LGCF, LFDI, LEP and LINF (Sims et al., 1990; Toda and Phillips, 1993). The outcomes of the Granger Causality tests with lags by three periods confirm our results that worker remittances do lead to greater output in the economy.

Table 5. Results of ECM for the Selected ARDL Dependent Variable: Real GDP $(\Delta L Y)$

\begin{tabular}{lllll}
\hline Variables & Coefficients & Std. Error & t-Statistics & Probability \\
\hline C & 1.844 & 0.219 & 8.404 & 0.000 \\
LY(-1) & -0.675 & 0.134 & -5.037 & 0.000 \\
LY(-2) & -0.449 & 0.123 & -3.649 & 0.002 \\
LWR & 0.025 & 0.009 & 2.701 & 0.013 \\
LWR(-1) & -0.020 & 0.009 & -2.122 & 0.046 \\
LGFCF & 0.211 & 0.035 & 5.996 & 0.000 \\
LFDI & 0.021 & 0.005 & 4.439 & 0.000 \\
LFDI(-1) & -0.019 & 0.005 & -3.868 & 0.001 \\
LEP(-2) & 0.087 & 0.022 & 3.918 & 0.001 \\
LINF & -0.014 & 0.005 & -2.574 & 0.018 \\
ECM(-1) & -0.109 & 0.013 & -8.246 & 0.000 \\
\hline
\end{tabular}

Diagnostic Tests: $R$-square $=0.844 ;$ Adjusted $R$ Square $=0.697$; Jarque-Bera Normality test $=$ 6.603(0.040); Breusch-Godfrey Serial Correlation test $=1.261(0.306) ; A R C H$ Heteroscedasticity test $=$ 0.394(0.678); andRamsay Reset, Regression specification Error test $=1.160(0.335)$. The values in parenthesis show $p$-values.

Table 6. VEC Granger Causality test (Wald test)

$$
X^{2}
$$

\begin{tabular}{lllllll}
\hline Causes & \multicolumn{7}{c}{} \\
\hline Effects & LY & LWR & LGFCF & LFDI & LEP & LINF \\
LY & & $9.91(0.01)$ & $4.78(0.09)$ & $0.57(0.75)$ & $0.82(0.67)$ & $2.55(0.28)$ \\
LWR & $3.74(0.15)$ & & $1.50(0.47)$ & $0.54(0.76)$ & $5.50(0.07)$ & $0.04(0.98)$ \\
LGFCF & $3.64(0.16)$ & $1.02(0.60)$ & & $4.57(0.10)$ & $0.38(0.82)$ & $0.00(0.99)$ \\
LFDI & $11.98(0.00)$ & $0.48(0.79)$ & $5.77(0.06)$ & & $0.59(0.05)$ & $1.04(0.60)$ \\
LEP & $0.45(0.80)$ & $0.35(0.85)$ & $0.06(0.97)$ & $0.18(0.91)$ & & $0.12(0.94)$ \\
LINF & $2.72(0.26)$ & $0.31(0.86)$ & $8.80(0.01)$ & $1.10(0.58)$ & $2.67(0.24)$ \\
\hline Notes: The Granger Causality tests are based on Wald test statistics, and they can be used to show the direction of \\
causality when the variables are integrated of order 1(1).
\end{tabular}

The study also applied the Impulse Response Functions (IRF) to examine the IRF change in economic growth due to a one-standard deviation shock to the explanatory variables. The outcome of the IRF in Table 7 and in Fig. 4 shows that economic growth responds positively to a one-standard deviation shock to worker remittances. The response of the GDP to shocks in worker remittances is positive and increases favorably over three periods after the introduction of the shocks. 
Response to Cholesky One S.D. Innovations \pm 2 S.E.

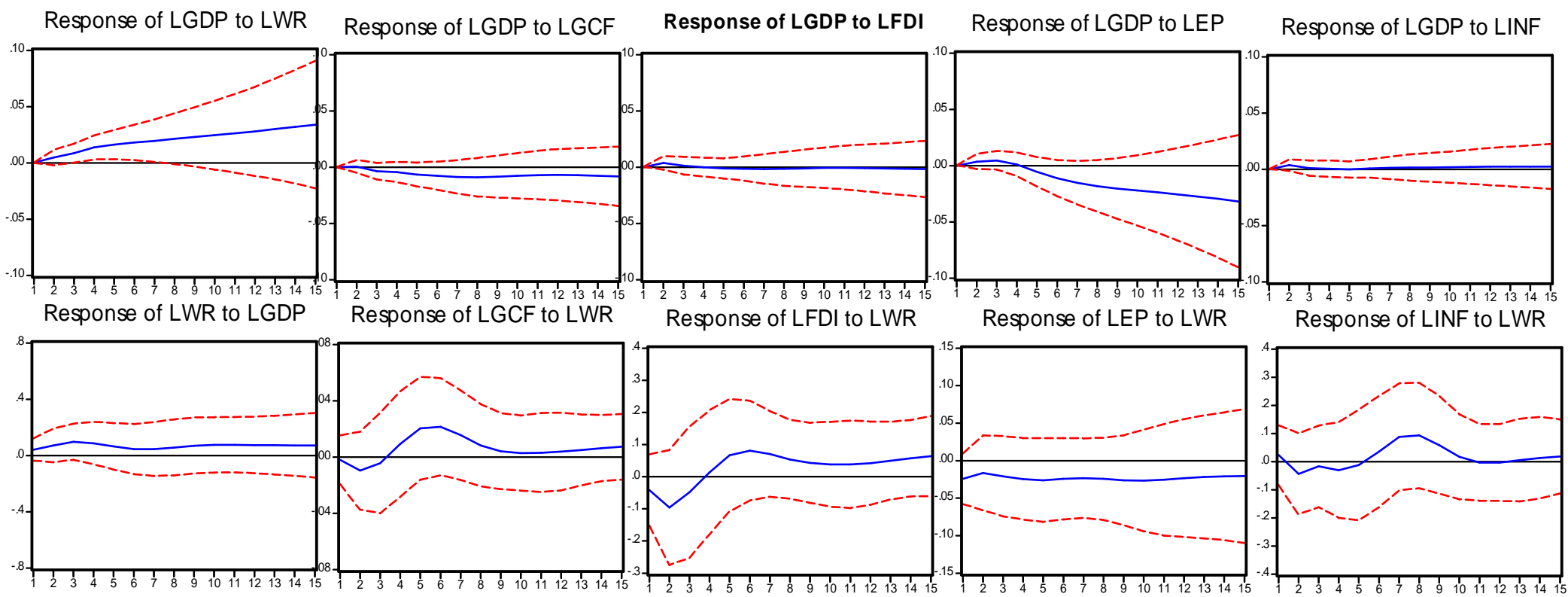

Fig. 4. Impulse response functions with one-standard-deviation shocks 
The responses of GFCF and FDI to worker remittances becomes insignificant up to 3 and 4 periods respectively and remains positive and significant up to 15 periods. However, the response of the export to workers remittance remains negative and shows a mixed response over the time horizon. The IRF shows that the effect of inflation on economic growth becomes insignificant after 2 periods but remains negative for up to 15 periods.

Table 7. Results of Impulse Response Functions

\begin{tabular}{llll}
\hline Shocks to & Response of & $\begin{array}{l}\text { Number of } \\
\text { Time Periods }\end{array}$ & Effect \\
\hline LWR & LY & 15 & $\begin{array}{l}\text { Positive and increasing over time } \\
\text { Negative and increasing over time } \\
\text { LGFCF }\end{array}$ \\
LFDI & & $\begin{array}{l}\text { Mixed effects } \\
\text { Positive and negative over time } \\
\text { Mixed effects }\end{array}$ \\
LEP & & Negative but positive over time \\
LINF & Negative but positive and increasing \\
LWR & LGFCF & 15 & $\begin{array}{l}\text { Ner time } \\
\text { Negative } \\
\text { Mixed effect }\end{array}$ \\
& LFDI & & \\
& LEP & & \\
\hline
\end{tabular}

\section{CONCLUSION \& SUGGESTION FOR FUTURE RESEARCH}

This study empirically examined the effects of worker remittance, gross fixed capital formation, FDI, exports and inflation on economic growth in Pakistan during the period 19762010. We applied the Bounds testing technique developed by Pesaran et al. (2001) together with ECM techniques to trace long-run and short-run relationships. The results showed a positive and significant relationship between worker remittances and economic growth in both the long-run and the short-run. The small magnitude of the remittance-growth coefficients in the short run could be due to the use of remittance to meet domestic requirements and to hedge against short-run economic instabilities. FDI effects on economic growth are positive and significant in the long-run as well as in the short-run. The impact of exports on economic growth is positive and insignificant in the long-run. The inflation rate affects economic growth negatively in both the long-run and the short-run. The Granger Causality test, which is based on the Wald test statistics, revealed that worker remittance does Granger-cause output in the economy. Moreover, the study analyzed the IRF response of economic growth by looking at one-standard deviation shocks over a 15-year time horizon, which showed that economic growth responds positively to worker remittances.

As the largest source of foreign capital, worker remittance act as a boon to the economy. They affect economic growth positively and become an important component of the BOP. Together, the inflow of worker remittances and FDI tend to boost economic activities and to reduce supply bottlenecks in Pakistan. The negative effect of gross fixed capital formation on economic growth and the small coefficient for export elasticity in the long run demonstrate the inappropriateness of current investment and export policies in Pakistan.

These financial flows, coupled with growing government expenditures, have increased the price level in the economy. This increase in the prices resulted in high-cost manufacturing activities, which have led to a general rise in the price level in the economy. Thus, inflation discourages high-cost investment and export competitiveness. Addressing instability in the 
economic growth response requires long-term commitments on the part of the real performers of the economy. It is likely that Pakistan can enhance their economic stability by enhancing economic activities on the external front. Given Pakistan's current environment, policy makers must address trade-offs between rising prices versus decreasing employment, high-cost debt servicing versus low domestic capital formation, low-cost import versus highcost export inelasticity and political instability versus economic security.

\section{COMPETING INTERESTS}

Author has declared that no competing interests exist.

\section{REFERENCES}

Adams, Richard, H., Jr. (1991). The effects of international remittances on poverty, inequality and development in rural Egypt. Research Reports 86, International Food Policy Research Institute (IFPRI).

Adams, R.H., Jr. (1998). Remittances, investment and rural asset accumulation in Pakistan. Economic Development and Cultural Change, 17(1), 155-173.

Adams, Richard, H., Jr., John, Page (2003). International migration, remittances and poverty in developing countries. Policy Research, Working Paper Series, 3179, World Bank.

Ahmed, Junaid, Zaman, Khalid, S.A., Iqtidar. (2011). An empirical analysis of remittancesgrowth nexus in Pakistan using bounds testing approach. Journal of Economics and International Finance, 3(3), 176-186, March 2011.

Anwar, T. (2004). Recent macroeconomic developments and implications for poverty and employment in Pakistan. Australia, Working Paper, South Asia Research Centre.

Asghar, Ashfaq (2004). Remittances not very productively employed. Daily Dawn, Islamabad, Pakistan 13-Sep. Online available at: www.dawn.com/2004/09/13/ebr9.htm.

Balassa, B. (1985). Exports, policy choices and economic growth in developing countries after the 1973 oil shock. Journal of Development Economics, 18, 23-35.

Barro, Robert, J., (1991). Economic growth in a cross section of countries. Quarterly Journal of Economics, 106, 407-43

Borensztein, E., De Gregorio, J., Lee J.W., (1998). How does foreign direct investment affect economic growth. Journal of International Economics, 45, 115-135.

Burney, N. (1987). Workers' remittances from the Middle East and their effect on Pakistan's economy. The Pakistan Development Review, 26(4), 745-61.

Burney, Nadeem (1988). A macroeconomic analysis of the impact of remittances from the Middle East on Pakistan's economy. WP No.8, ILO-UN Project.

Cameron, S. (1994). A review of the econometric evidence on the effects of capital punishment. Journal Socio-Economic, 23, 197-214.

Catriescu, N.C., Leon-Ledesma, M., Piracha, M. (2006). Remittances, institution and growth. Discussion Paper no. 2139, The Institute for the Study of Labor (IZA), University of Bonn, Germany.

Carlos, V.S., Huang, P. (2006). Macroeconomic determinants of workers' remittances: Host versus home country's economic conditions, Journal of International Trade \& Economic Development, Taylor and Francis Journals, vol. 15(1), pages 81-99.

Chami, Ralph., Connel, F.K., Samir Jahja. (2003). Are immigrants remittances flows a source of capital for development. (IMF Working Paper, WP/03/189). 
Denison, E.F., (1967). Why growth rates differ', the Brookings institution (Washington).fabricant, ehrlich, I.1996. 'crime, punishment and the market for offences. Journal of Economic Perspectives, 10, 43-67.

De Gregorio, J. (2003). The Role of foreign direct investment and natural resources in economic development. Central Bank of Chile Working Paper No. 196 (Santiago: Central Bank of Chile).

De Mello, L.R., Jr. (1997). Foreign direct investment and economic growth: a selective survey. Journal of Development Studies, 34, 1-34.

Docquier, F., Rapoport, H. (2006). Globalization, brain drain and development. S. Kolm \& Jean Mercier Ythier (ed.), 2006. Handbook of the Economics of Giving, Altruism and Reciprocity, Elsevier, edition 1, 2(2).

Faini, Riccardo. (2002). F. proceedings from the ABCDE Europe Conference, 1-2, 85-116.

Fayissa B., Nsiah, C. (2008). The impact of remittances on economic growth and development in Africa. Department of Economics and Finance, Working paper Series, February, 2008. Online available at: http://ideas.repec.org/p/mts/wpaper/200802.html.

Giuilano, P., Arranz, M.R., (2005). Remittances, financial development and growth. IMF, Working Paper No. 05/234, International Monetary Fund, Washington DC.

Gylfason, T. (1999). Exports, Inflation and Growth, World Development 27, 1031-1057,

Habib,Md.R., Nourin, S. (2006). Remittances and real investment: an appraisal on South and South East Asian economies. Faculty of Economics, Chulalongkorn University, Asian Institute of Technology, Bangkok Online available at: http://www.doaj.org/doaj?func=abstract\&id=243088.

Hodge, D. (2006). Inflation and growth in South Africa. Cambridge Journal of Economics, 30, 163-180.

Iqbal, Z., Sattar, A. (2005). The Contribution of workers' remittances to economic growth in Pakistan. Research Report No. 187, Pakistan Institute of Development Economics, Islamabad.

Jongwanich, J. (2007). Workers' remittances, economic growth and poverty in developing Asia and the Pacific. UNESCAP Working Paper, WP/07/01, January.

Kaufmann, Daniel, Aart Kraay, Massimo Mastruzzi. (2006). Governance matters VII: aggregate and individual governance indicators for 1996-2005. World Bank Policy Research Working Paper No. 4012, Washington, D.C.

Kalim, R., Shahbaz, M. (2009). Remittances and poverty nexus: evidence from Pakistan. Int'l Res. J. of Finance and Econs, Issue 29, 46-59. ISSN: 1450-2887.

Kemal, A.R., Musleh ud Din, U., Qadir. (2002). Exports and Economic Growth in South Asia. A Study Prepared for the South Asia Network of Economic Research Institutes.

Khan, A.H., Saqib, N. (1993). Exports and economic growth, the Pakistan experience. International Economic Journal, 7, 53-64.

Krueger, A.O. (1978).Foreign trade regimes and economic development: liberalization attempts and consequences. Ballinger Publication Company, Cambridge.

Layson, S. (1983). Homicide and Deterrence: Another view of the Canadian time series evidence. Canadian Journal of Economics, 16, 52-73.

Lewis, W.A. (1954). Economic development with unlimited supply of labour. Manchester School of Economic and Social Studies, 22, 139-191

Lucas, R.E.B., Stark, O. (1985). Motivation to remit: evidence from Botswana. Journal of Political Economy, 93(5), 901-918.

McCormick, Barry, Jackline Wahba. (2000). Overseas employment and remittances to a dual economy. The Economic Journal, 110, 509-34.

Nishat, M., Nighat Bilgrami. (1991). The Impact of Migrant Workers' remittances on Pakistan's Economy. Pakistan Econ. Social Rev., 29, 21-41 
Narayan, P.K. (2005). Estimating income and price elasticities of imports for Fiji in a cointegration framework. Econ. Model, 22, 423-438.

Orozco, Manuel (2003). Workers' remittances in an international scope. Working Paper Commissioned by the Multilateral Investment Fund of the Inter-American Development Bank'.

Owens, E. (1987). The future of freedom in the developing world. Pergamum Press.

Pesaran, M.H., Shin, Y., Smith, R. (2001). Bounds testing approaches to the analysis of level relationships. J. Appl. Econ., 16, 289-326.

Rajan, Ramkishen, S. (2006). The importance of workers' remittances as a source of development finance. Working Paper. School of Public Policy, George Mason University.

Ratha, D. (2007). Leveraging remittances for development. Policy Brief, Migration Policy Institute, Washington DC.

Reichart, Joshua. (1981). The migrant syndrome: seasonal U.S. wage labour and rural development in central Mexico. Human Organization, 40, 56-66.

Romer, Paul. (1986). Increasing returns and long-run growth. Journal of Political Economy, 94(5), 1002-37.

Salvatore, D., Hatcher, T. (1991). Inward and outward oriented trade strategies. Journal of Development Studies, 27, 7-25.

Shahbaz, M., Jamshaid, R., Waqar, H. (2008). Does foreign remittances reduce government spending. Int. Res. J. Finance and Econ., 14, 239-253.

Sims, C.A., Stock, J.H., Watson, M.W. (1990). Inference in linear time series model with some unit roots. Econometrica, 58, 113-144.

Solow, R.M. (1956). A contribution to the theory of economic growth. The Quarterly Journal of Economics, 70(1), 65-94.

Stahl, Charles, W., Fred Arnold. (1986). Overseas workers' remittances in Asian Development. International Migration Review, 20(4), 899-925

Stark, O., Bloom, D. (1985). The new economics of labour migration'. American Economic Review, 75, 173-8.

State Bank of Pakistan. (2011). Annual Report. State Bank of Pakistan.

Toda, H.Y., Phillips, P.C.B. (1993). Vector autoregression and causality. Econometrica, 59, 229-255.

Tyler, W.G. (19981). Growth and export expansion in developing countries: some empirical evidence. Journal of Development Economics, 9, 121-130.

UNCTAD. (2011). Hand Book of Statistics, 2011. UNCTAD.

World Bank. (2006). Global economic prospects 2006: economic implications of remittances and igration'. Washington D. C.

Vohar, R. (2001). Exports and economic growth, further time series evidence from less developing countries. International Advance in Economic Research, 7, 345-350.

World Bank. (2011). World Development Indicators (WDI). Washington, D.C. 


\section{APPENDIX 1}
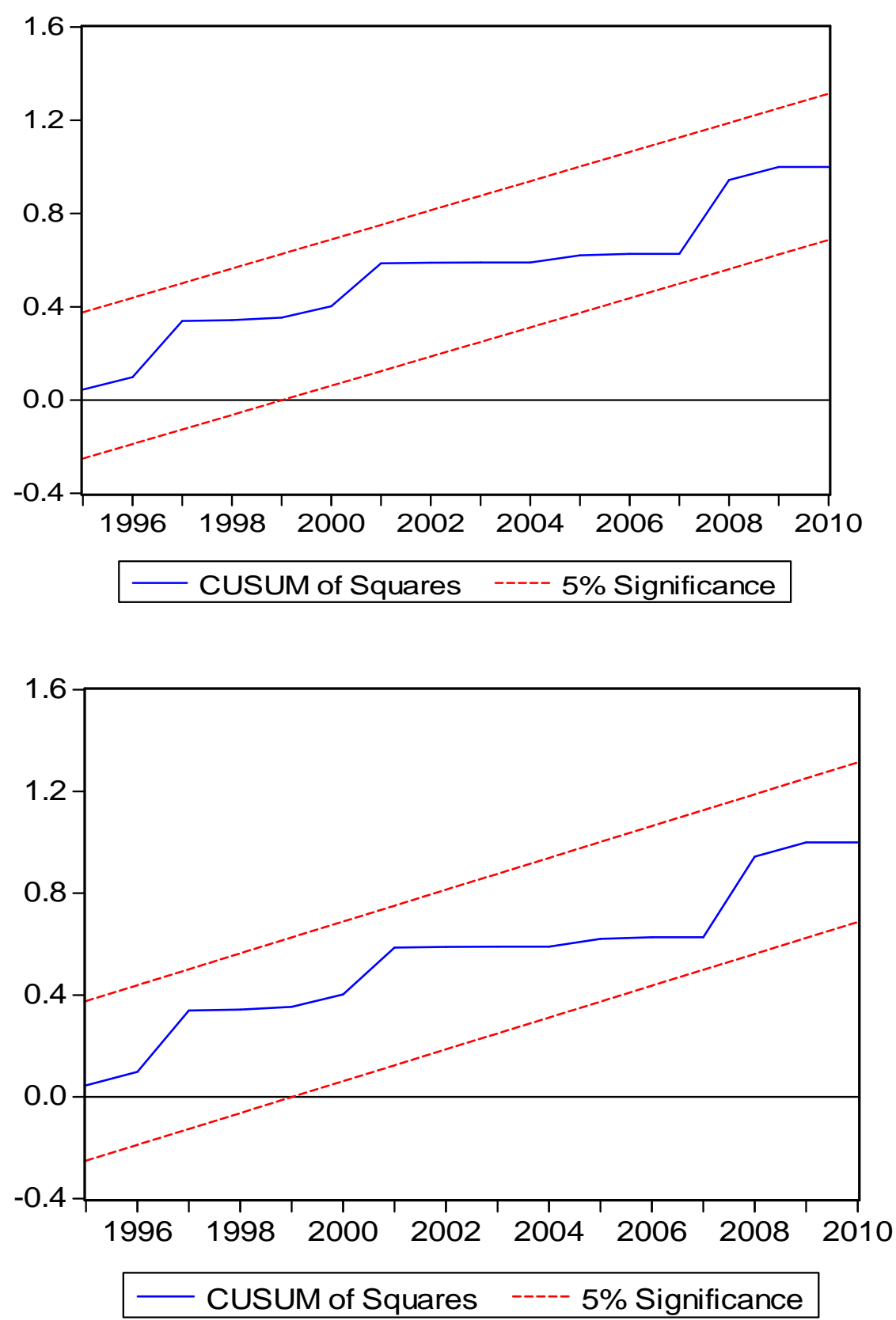

C 2012 Khathlan; This is an Open Access article distributed under the terms of the Creative Commons Attribution License (http://creativecommons.org/licenses/by/3.0), which permits unrestricted use, distribution, and reproduction in any medium, provided the original work is properly cited. 